\title{
Social media as a learning tool for healthcare professionals: is it really possible?
}

\author{
A mídia social como ferramenta de aprendizagem para profissionais de saúde: é mesmo possível? \\ Las redes sociales como herramienta de aprendizaje para los profesionales sanitarios: ¿es realmente
} posible?

Carlos Gabriel de Lade

ORCID: https://orcid.org/0000-0002-6924-5335 Faculdade Ensine, Brazil

E-mail: lade.gab@gmail.com

Helder Barra de Moura

ORCID: https://orcid.org/0000-0002-6026-8645 Faculdade Ensine, Brazil

E-mail: prof.helder.moura@ensin-e.edu.br

Helder Zimmerman de Oliveira ORCID: https://orcid.org/0000-0001-6451-5212 Faculdade Ensine, Brazil

E-mail: prof.helder.oliveira@ensin-e.edu.br

Fernanda Dias Coelho

ORCID: https://orcid.org/0000-0002-8002-9510 Faculdade Ensine, Brazil

E-mail: diascoelhofernanda@gmail.com

Marcionilo Euro Carlos Neto

ORCID: https://orcid.org/0000-0002-6714-2404 Faculdade Ensine, Brazil

E-mail: netoscout@hotmail.com

Raphael Soares

ORCID: https://orcid.org/0000-0003-1658-8868 Faculdade Ensine, Brazil

E-mail: prof.raphael.soares@ensin-e.edu.br

Santiago Tavares Paes

ORCID: https://orcid.org/0000-0002-5935-0836 Faculdade Ensine, Brazil

E-mail: santtpaes@hotmail.com

\begin{abstract}
The aim of this study is to stimulate discussion about the potential of social media as an important learning tool for healthcare professionals through a critical review of the literature. We conducted a critical brief review of the literature published from 2010 to 2021 in PubMed, using the search terms "social media", "healthcare professional", "online learning", "online education", and "medical education", and some variations according to MeSH. Besides the Pubmed database, searches were conducted through the website https://mededu.jmir.org/. Many healthcare professionals use social media to find and share health information, communicate with colleagues and trainees, advertise their clinical practices, engage in health advocacy, impact health policy decisions, exchange developments in their fields, and publicize their research. However, this is still a topic without established conclusions. Although many studies describe social media as important tools to improve the learning of health students regarding communication, professionalism and ethics, limitations related to health information found in social media are the lack of quality and reliability. In conclusion, we recognize the numerous potential strengths of social media as educational tools, but many points are still unclear and need to be persistently understood, evaluated, and discussed.
\end{abstract}

Keywords: Social media; Healthcare professional; Online learning; Online education; Medical education.

\section{Resumo}

O objetivo deste estudo é estimular a discussão sobre o potencial das mídias sociais como uma importante ferramenta de aprendizagem para profissionais de saúde por meio de uma revisão crítica da literatura. Realizamos uma breve revisão crítica da literatura publicada de 2010 a 2021 no PubMed, usando os termos de pesquisa "mídia social", "profissional de saúde", "aprendizagem online", "educação online" e "educação médica" e algumas variações de acordo com MeSH. Além da base de dados Pubmed, foram realizadas buscas no site https://mededu.jmir.org/. Muitos profissionais de saúde usam a mídia social para encontrar e compartilhar informações sobre saúde, comunicar-se com colegas e estagiários, anunciar suas práticas clínicas, se envolver na defesa da saúde, influenciar as decisões de políticas 
de saúde, trocar desenvolvimentos em seus campos e divulgar suas pesquisas. No entanto, este ainda é um tema sem conclusões estabelecidas. Embora muitos estudos descrevam as mídias sociais como ferramentas importantes para melhorar o aprendizado de estudantes de saúde no que diz respeito à comunicação, profissionalismo e ética, as limitações relacionadas às informações de saúde encontradas nas mídias sociais são a falta de qualidade e confiabilidade. Em conclusão, reconhecemos os inúmeros pontos fortes potenciais das mídias sociais como ferramentas educacionais, mas muitos pontos ainda não estão claros e precisam ser persistentemente compreendidos, avaliados e discutidos. Palavras-chave: Mídia social; Profissional de saúde; Aprendizagem online; Educação online; Educação médica.

\section{Resumen}

El objetivo de este estudio es estimular la discusión sobre el potencial de las redes sociales como una importante herramienta de aprendizaje para los profesionales de la salud a través de una revisión crítica de la literatura. Realizamos una breve revisión crítica de la literatura publicada de 2010 a 2021 en PubMed, utilizando los términos de búsqueda "redes sociales", "profesional de la salud", "aprendizaje en línea", "educación en línea" y "educación médica", y algunas variaciones. según MeSH. Además de la base de datos Pubmed, las búsquedas se realizaron a través del sitio web https://mededu.jmir.org/. Muchos profesionales de la salud utilizan las redes sociales para buscar y compartir información sobre salud, comunicarse con colegas y aprendices, publicitar sus prácticas clínicas, participar en la defensa de la salud, influir en las decisiones de políticas de salud, intercambiar desarrollos en sus campos y dar a conocer sus investigaciones. Sin embargo, este es todavía un tema sin conclusiones establecidas. Aunque muchos estudios describen las redes sociales como herramientas importantes para mejorar el aprendizaje de los estudiantes de salud en cuanto a comunicación, profesionalismo y ética, las limitaciones relacionadas con la información de salud que se encuentran en las redes sociales son la falta de calidad y confiabilidad. En conclusión, reconocemos las numerosas fortalezas potenciales de las redes sociales como herramientas educativas, pero muchos puntos aún no están claros y deben ser entendidos, evaluados y discutidos de manera persistente.

Palabras clave: Medios de comunicación social; Profesional de la salud; Aprender en línea; Educación en línea; Educación médica.

\section{Introduction}

Social media has become an integral method of communication for a vast majority of our digitally connected society (Madanick, 2015) and has a tremendous impact upon every facet of our personal and professional lives (Faizi et al., 2013). Due to the universal nature and pervasive informational function of interactive digital and mobile technologies, social media has now transformed from being used informally in educational settings to gaining formal acceptance by students, faculty, and administrators (Piotrowiski, 2015). Representing a new paradigm in education, Web 2.0 communications, encompasses a wide variety of services, such as blogs, and social networks (Moran et al., 2011).

Given that a large number of internet users are teachers and students, social media seem to have greatly influenced the way we teach and learn. Therefore, the role of emerging social media may offer new opportunities to enhance the teaching and learning experiences (Alabdulkareem, 2015). According to Zepke e Leach (2010), the motivation and student dispositions will influence their ability to engage in interactive learning. Social media are infiltrating the educational area. The online social networks are increasingly being used not only by college students, but also by instructors for different reasons. Nonetheless, despite the high popularity of personal use of online social media, a low percentage of students and instructors use them for educational purposes (Chen \& Bryer, 2012), although for the purpose of education social media has been used as an innovative way (Siddiqui \& Singh, 2016).

A major educational implication of social media is the apparently changing nature of learners' relationships with information and knowledge. Indeed, it could be argued that social media support forms of knowledge consumption and knowledge construction that are very different to the epistemological principles of formal education and individualized instruction (Selwyn, 2012). Healthcare information is constantly changing as new clinical evidence becomes available. It is suggested that clinical practice guideline recommendations are often outdated within 6 years of publication (Pizzuti et al., 2020).

Social media platforms have the potential to aid the individual practitioner in notifications of newly published evidence and pipeline data. While this could be a potential outlet for acquiring or alerting to new, evidence-based information, the using social media as a learning tool for healthcare professionals is still controversial, but it needs to be discussed. Therefore, the aim 
of this study is to stimulate discussion about the potential of social media as an important learning tool for healthcare professionals through a critical review of the literature.

\section{Methodology}

This research comprises a synthetic approach to expert opinion on the use of the media as a learning tool for healthcare professionals. It is a critical brief review of several studies that address the proposed theme, where positive and negative points and some suggestions are present in this study. The search for studies related to the topic occurred in the PubMed database using combinations of the keywords "social media", "healthcare professional", "online learning", "online education", and "medical education", and some variations according to $\mathrm{MeSH}$. The choice of studies included in this work occurred in a non-systematic way, that is, they were selected based on their relevance to the problem addressed. Besides the Pubmed database, searches were conducted through the website https://mededu.jmir.org/. The year 2010 represented a turning point in the number of publications about social media in various outcomes. As a result, we considered the inclusion of studies published from this date.

\section{Results and Discussion}

With technological evolution, academic and research interest in using social media as learning tools has increased in contemporary educational institutions. Although research on this topic has grown exponentially in recent years, very little is known about the breadth of social media research in the academic literature, and little evidence on the potential for using social media in education is known. Social media is, however, a universe of tools, sites and online experiences that are rapidly evolving. It is very likely that this topic is too broad and too new for us to reach definitive conclusions, and further discussion and views are needed.

The use of social media is not just limited to recreation but is also widely used in educational sectors by students. It's no secret that most students and teachers have smartphones and have used social media in education. There are web apps and tools that offer social media in an educational context. With faculty using a variety of software tools and free web applications to enhance learning, communication, and engagement, social media use is increasing in higher education classrooms (Raut \& Patil, 2016).

According to previous research, $90 \%$ of college students use social networks. Technology has shown a rapid development by introducing small communication devices and we can use these small communication devices for accessing social networks any time anywhere (Siddiqui \& Singh, 2016). In the educational system, social media has been considered a great innovation, but students must be taught to use this tool in a more assertive way, which is exploring its enormous potential (Kalia, 2013). In addition, several areas of health are participating in the generation of content shared on social networks as a form of education, professional marketing or improving the quality of life of the followers. For this reason, the character of teaching, production and sharing of scientific information is already attributed to social media (Wong \& Liu, 2019).

The use of social media for educational purposes of producing and recording classes, lectures, meetings, and symposia on topics associated with improving health and quality of life is already a reality in several countries, which confirms the need to look at these tools as a didactic alternative and pedagogical for training both the lay public and the professionals themselves, evidently in the light of science and scientific foundation (Alanzi \& Al-Habib, 2020; Paes et al, 2021).

The use of social media by healthcare professionals is a growing topic of debate and current research focus. However, this is still a topic without established conclusions, requiring further studies in this area. Then, based on the analysis of the literature, we establish and discuss the positive points and also the counterpoints regarding the use of social media for educational purposes for health professionals. 


\subsection{Education of healthcare professionals and social media}

Like contemporary education in other subjects, health education has recently experienced an evolving shift from teaching to learning which has been strongly related to an increasing use of information and communication technologies and the web (Paton et al., 2011).

Pizzuti et al. (2020) evaluated the opinions of health professionals regarding the use of social media for educational purposes. Nearly $85 \%$ agreed or strongly agreed that social media can be an effective tool for educational purposes. Among those who had social media platforms, $43 \%$ use them for educational purposes. Regarding educators, as the use of social media grows in popularity, health educators are challenged to think differently about how to communicate with the public, students, and professionals.

Hanson et al. (2011) analyzed social media use and the factors that determine acceptance of social media use among health educators. The results revealed that health educators most commonly use social networking sites (34.8\%), podcasts $(23.5 \%)$ and media sharing sites $(18.5 \%)$ within their organizations and concluded that many educators are using social media in their teaching practices. The authors recognize that the use of social media can represent a methodology with potential support to improve the practice of health education. However, implementation must include attention to guidelines and best practices.

Medical education is rapidly moving into a post-COVID world, with the use of social media becoming ever more prominent. Considering this specific situation, D'souza et al. (2021) analyzed the possible risks and benefits of using social media to aid learning in medical education. Benefits include accessibility to experts, opportunities for mentorship, access to support networks, resource sharing and global participation. Key criticisms focus on superficial learning, psychological safety, correctly identifying level of expertise, professionalism degree and ownership protections for content creators.

Health professionals and researchers may use social media for their own professional development such as learning, collaboration, and career advancement. Social media can be used to collaborate on research projects and practices, access and share trending research findings and medical knowledge, broaden their exposure to funders and publishers, conduct a job search, follow medical conferences remotely, market their team and services, and discuss interesting or difficult cases with other professionals (Chen \& Wang, 2021). According to the same authors, studies have found that different social media platforms play different roles in the professional development of health professionals and researchers. Medicine seems to be one of the prominent areas to use these tools as a way of training students in training or updating professionals who have already graduated. That is, medical education is already a reality and has ramifications beyond the limits of the classroom, which makes social media a link between formal and informal learning, given the great capacity to maintain the engagement and involvement of students with educational content outside the classroom (El Bialy \& Jalali, 2015).

Many healthcare professionals use social media to find and share health information, communicate with colleagues and trainees, advertise their clinical practices, engage in health advocacy, impact health policy decisions, exchange developments in their fields, and publicize their research. Beyond social networking, healthcare professionals have historically used social media platforms to directly engage and educate professional peers, house staff trainees, and patients. Thus, several healthcare professionals have already understood that, given the new digital age of access to information, it is necessary to use social media as a way of raising awareness and disseminating knowledge (EL Bialy \& Jalali, 2015; Pizzuti et al., 2020; Alanzi \& AL-Habib, 2020; Carpenter et al., 2020). For this, science needs a language accessible to users and that can translate robust scientific information in health into a technical language that is simple and that the texts attributed to the posted content are succinct and easy to understand for the lay public. That is, most health professionals agree that social media can be a great ally in public health education and in improving audiovisual communication skills regarding health content (Paes et al., 2021).

The advent of COVID-19 further catalyzed the adoption of social media platforms to disseminate information more rapidly about an unknown and contagious disease directly to frontline reporters as new information unfolded. This was critical 
in many instances, such as providing guidance on helping health care workers to maintain safety during aerosolizing procedures like endotracheal intubation. The COVID-19 pandemic also disrupted medical education. It forced medical schools and residency and fellowship training programs to adapt to how they educate their trainees (Katz \& Nandi, 2021).

The use of mobile hardware and healthcare-related applications (mHealth) are on the rise by patients, healthcare professionals, educators, and learners. mHealth provides access to multiple information sources instantaneously influencing all individuals at the global level who have access to the mobile tools and are being used to narrow the communication gap between patients and healthcare professionals, as well as between educators and learners (Paton et al., 2011). Health associations state the need for healthcare professional education to include health information technology skills/competencies in fundamental nursing education, for example. Educators need to look at and consider the wireless, mobile learning experiences in higher education in order to stay abreast of the latest technologies affording students' heightened learning and understanding. These are some examples of how current healthcare professional students learn differently than students in the not so distant past. Healthcare professional education is being enhanced by wireless handheld mobile technology.

Chan and Leung (2020) evaluated the feasibility of an intervention aiming to investigate the effects of a continuing professional education program using Facebook to gain knowledge about dementia and care for patients with dementia. The learning materials were developed by a team of experts from the relevant disciplines, including medicine, nursing, pharmacy, occupational therapy, speech therapy, and social sciences, to provide updated interdisciplinary knowledge on dementia care. The results demonstrate that Facebook is a promising tool for professional education. Participants demonstrated positive attitudes toward utilizing Facebook for professional learning. A recent work by Abbas and Ojha (2019) evaluated the application of the YouTube channel "Not Just a Medical Student", which attempts to innovatively apply social media to the advancement of medical education. In conclusion, they claim that innovative methods in the educational process that use social media can directly contribute to medical education, should be encouraged and their unique properties allow new innovative teaching-learning experiences to be implemented.

\subsection{Points and counterpoints}

Although many studies describe social media as important tools to improve the learning of health students regarding communication, professionalism and ethics, limitations related to health information found in social media are the lack of quality and reliability. Much health information found on social media is not properly referenced, incomplete and limited (Ventola, 2014). Similar problems exist with traditional online media. However, the open access and lack of filters for social media content magnifies these problems as any user can upload content. In addition, social media content consumers can also be vulnerable to hidden conflicts of interest (with financial interests) and are often not able to identify (Pirraglia \& Kravitz, 2012; Moorhead et al., 2013). When this content is used for continuing education, obtaining information, and updating by healthcare professionals, it can become a very serious problem.

One of the main problems involved in obtaining information through social media is related to the quality and reliability of this information. When this information involves the health field and is used as a source of learning and updating by health professionals, the consequences can be devastating. The consequences related to "learning" for unreliable information may reflect negatively on the performance of health professionals who consume social media content for educational purposes. On the other hand, the professional image of those who disseminate unreliable information can also be seriously undermined. According to Wilkinson and Ashcroft (2019), professionals are susceptible to false information, and such content can easily be distributed if time is not taken for confirmation and review.

During the COVID-19 pandemic, social media became important allies for the dissemination of information about a disease that is still little known. However, these same social media were used as vehicles for transmitting false news and 
misinformation, mainly related to treatments without scientific evidence, vaccines, and prevention measures, such as the use of masks and social distancing. The most serious is that these contents were disseminated by health professionals with the aim of providing guidance (teaching) to other health professionals. a clear example of this situation is related to the role of Twitter in facing false news. In response to the spread of fake news concerning the COVID-19 pandemic, Twitter accelerated its verification process to endorse the credibility of specialist accounts by adding a blue tick next to their names (D`Souza et al., 2021).

Another point that deserves to be highlighted is to investigate which social media has the greatest capacity for instruction and education according to its characteristics. It is known that it is possible to use the media for hybrid education, but it is important to understand what the factors can amplify this teaching capacity and how users identify with information posted in these tools.

The reach of information transmitted by social media is a very striking feature of these tools. On the one hand, this fact can be considered positive. However, considering information that aims to guide or update other health professionals, other characteristics must be considered. One of these characteristics is related to the limited space for writing, which directly limits the deepening of the topic addressed. As a result, superficial information can be used in a generalized way and without the necessary rigor in professional practice.

\section{Final Considerations and Future Perspective}

The growth of social media in recent years has transformed the way the Internet is experienced by most end users. Amidst these technological advances, many higher education institutions, educators, students, and professionals from different areas of knowledge realized the potential of the internet, especially social media, to consume or develop programs related to educational activity. The highly connected, collective, and creative environment of social media reflects and drives more flexible, fluid, and fast-paced lifestyles. For enthusiasts, the increased presence of social media in higher education environments is essential for universities to connect with these students, for example. Given that the growing use of social media platforms to interact, generate, access, and disseminate information is an increasingly used practice among health professionals, it is pertinent to take a closer look at issues that can directly influence the quality of information transmitted and, consequently, consumed. Information related to all areas of health emerges and is updated quickly, and the volume of this new information has never been greater.

Health professionals must be attentive and critical in relation to obtaining information and maintaining an updated database that is relevant to professional practice. A published literature review on the use of social media in medical education exposed some important points that should be considered. The authors concluded that there is little high-quality evidence, infrequent assessment of skills, behavior-based outcomes, and no outcome assessment involving study participants. More troubling is the claim that without structure, and forms of control, social media can negatively impact learning (Cheston et al., 2013). Although this work was published a few years ago, we believe that its conclusions still apply today.

The use of social media in education, updating and guidance of healthcare professionals from all areas is already considered a reality. However, despite the body of evidence having increased dramatically in recent years, some considerations still need to be made in relation to the real transformation of social media into a potential educational tool for healthcare professionals. Some important points were addressed throughout this study in relation to social media by health professionals that deserve attention. Superficial information, without references, incomplete, misleading, unreliable, biased and without mentioned conflicts of interest are variables that can be raised and used to question the use of social media in education, updating and guidance of healthcare professionals in all areas.

The presence of conflicts of interest in social media content must always be considered and directly impact both the vectors and the recipients of information. Healthcare professionals who use social media as a way of updating and learning need 
to be aware of possible conflicts of interest of the authors of publications. Biased information can become a major problem when applied indiscriminately in all fields of professional health practice. In relation to information transmitters, ensuring the transparency of information includes the declaration of conflicts of interest and good precepts for the interpretation and communication of scientific data. These points reduce the risk of bias, respect professional ethical principles and ensure more reliable information to healthcare professionals who use social media for learning purposes. Furthermore, these actions legitimize the use of these platforms as educational tools.

Different social media platforms have different and very particular characteristics. These peculiarities can directly influence the depth in which content is approached and transmitted. For example, the size of videos and the limited number of characters can make complex content to be approached in a simple way. As a suggestion, some social media platforms could develop and apply specific profiles for education and science, where control filters could be applied, as well as more space to approach content through images, videos, and writing.

This brief review aimed to stimulate a discussion about the use of social media as learning tools by healthcare professionals from all areas. Interest in this issue has increased significantly since 2010 and the literature has advanced on this topic. We recognize the numerous potential strengths of social media as educational tools, but many points are still unclear and need to be persistently understood, evaluated, and discussed.

\section{References}

Abbas, N. \& Ojha, U. (2019). Not Just a Medical Student: Delivering Medical Education Through a Short Video Series on Social Media. JMIR Med Educ, 5(1): e11971

Alabdulkareem, S. A. (2015). Exploring the Use and the Impacts of Social Media on Teaching and Learning Science in Saudi. Procedia Soc Behav Sci, 182, 213-224.

Alanzi, T. \& Al-Habib, D. K. (2020). The Use of Social Media by Healthcare Quality Personnel in Saudi Arabia. J Environ Public Health. $2020: 1417478$.

Carpenter, J. P.; Morrison, S. A.; Craft, M.; Lee, M. (2020). How and why are educators using Instagram? Teach Educ. 96:103149.

Chan, W. S. Y. \& Leung, A. Y. M. (2020). Facebook as a Novel Tool for Continuous Professional Education on Dementia: Pilot Randomized Controlled Trial. J Med Internet Res, 22(6), e16772.

Chen, B. \& Bryer, T. (2012). Investigating instructional strategies for using social media in formal and informal learning. The International Review of Research in Open and Distributed Learning, 13(1),87-104.

Cheston, C. C., Flickinger, T. E., Chisolm, M. S. (2013). Social Media Use in Medical Education: A Systematic Review. Acad Med, 88, 893-901.

Chen, J. \& Wang, Y. (2021). Social Media Use for Health Purposes: Systematic Review. J Med Internet Res, $23(5):$ e17917.

D'souza, F., Shah, S., Oki, O., Scrivens, L., Guckian, J. (2021). Social media: medical education's double-edged sword. Future Healthc J, 8(2): e307-e310.

El Bialy S., \& Jalali, A. (2015). Go Where the Students Are: A Comparison of the Use of Social Networking Sites Between Medical Students and Medical Educators. JMIR Med Educ. 1(2):e7.

Hanson, C., West, J., Neiger, B., Thackeray, R., Barnes, M. \& McIntyre, E. (2013). Am J Health Educ, 42(4), $197-204$.

Kalia, G. (2013). A Research Paper on Social media: An Innovative Educational Tool. Issues Ideas Educ, 1, 43-50.

Katz, M. \& Nandi, N. (2021). Social Media and Medical Education in the Context of the COVID-19 Pandemic: Scoping Review. JMIR Med Educ, 7(2):e25892.

Madanick, R, D, (2015). Education Becomes Social: The Intersection of Social Media and Medical Education. Gastroenterology, $149(4), 844-847$.

Moorhead, S. A., Hazlett, D. E., Harrison, L., Carroll, J. K., Irwin, A. \& Hoving, C. (2013). A New Dimension of Health Care: Systematic Review of the Uses, Benefits, and Limitations of Social Media for Health Communication. J Med Internet Res, 15(4):e85.

Moran, M., Seaman, J. \& Tinti-Kane, H. (2011). Teaching, Learning, and Sharing: How Today’s Higher Education Faculty Use Social Media. Babson Survey Research Group.

Paes, S. T., Scapim, S. N., Lade, C. G., Moura, H. B., Oliveira, H. Z., Coelho, F. D., Soares, R. \& Neto, M. E. C. N. (2021). Is it possible to teach good health practices using social media? Research, Society and Development, 10(12).

Paton, C., Bamidis, P., Eysenbach, G., Hansen, M. M. \& Cabrer, M. (2011). Experience in the Use of Social Media in Medical and Health Education. Yearb Med Inform, 6, 21-29. 
Research, Society and Development, v. 10, n. 15, e49101522371, 2021

(CC BY 4.0) | ISSN 2525-3409 | DOI: http://dx.doi.org/10.33448/rsd-v10i15.22371

Pirraglia, P. A. \& Kravitz, R. L. (2012). Social Media: New Opportunities, New Ethical Concerns. J Gen Intern Med, 28(2), 165-166.

Pizzuti, A. G., Patel, K. H., Mccreary, E. K., Heil, E., Bland, C. M., Chinaeke, E., Love, B. L. \& Bookstaver, P. B. (2020). Healthcare practitioners' views of social media as an educational resource. PLoS One. 15(2): e0228372.

Raut, V. \& Patil, P. (2016). Use of Social Media in Education: Positive and Negative impact on the students. International Journal on Recent and Innovation Trends in Computing and Communication, 4(1), 281-285.

Selwyn, N. (2012). Social Media in Higher Education. The Europa World of Learning 2012.

Siddiqui, S. \& Singh, T. (2016). Social Media its Impact with Positive and Negative Aspects. International Journal of Computer Applications Technology and Research, 5(2), 71-75.

Ventola, C. L. (2014). Social Media and Health Care Professionals: Benefits, Risks, and Best Practices. PT, 39(7), 491-499, 520.

Wilkinson, A. \& Ashcroft, J. (2019). Opportunities and Obstacles for Providing Medical Education Through Social Media. JMIR Med Educ, 5 (2):e15297.

Wong, X. L. \& Liu, R. C.; Sebaratnam, D. F. (2019). Evolving role of Instagram in \#medicine. Intern Med J, 49(10), 1329-1332.

Zepke, N. \& Leach, L. (2010). Improving student engagement: Ten proposals for action. Active Learning in Higher Education, 11(3), 167-177. 